\title{
Investigating the Relationships Between Organizational Change, Organizational Climate, and Organizational Performance
}

\author{
Sri Supriyati ${ }^{1}$, Udin $\operatorname{Udin}^{2}$, Sugeng Wahyudi ${ }^{1} \&$ Mahfudz Mahfudz ${ }^{1}$ \\ ${ }^{1}$ Business and Economics Faculty, Diponegoro University, Semarang, Indonesia \\ ${ }^{2}$ Business and Economics Faculty, Universitas Muhammadiyah Yogyakarta, Yogyakarta, Indonesia \\ Correspondence: Udin Udin, Business and Economics Faculty, Universitas Muhammadiyah Yogyakarta, Yogyakarta, \\ Indonesia.
}

Received: July 9, 2019

Accepted: August 4, 2019

Online Published: August 14, 2019

doi:10.5430/ijfr.v10n6p88

URL: https://doi.org/10.5430/ijfr.v10n6p88

\begin{abstract}
This study aims to analyze the effect of organizational change (i.e., technostructure change, work procedure, and individual) on organizational climate and organizational performance. By using the census technique, the respondents are all employees of regional drinking water company (PDAM) in Kendal regency of Indonesia. Data are analyzed using simple and multiple regression analysis. The results show that technostructure change partially has a significant negative effect on organizational climate, while work procedure and individual change have a significant positive effect on organizational climate. Furthermore, organizational change simultaneously has a significant positive effect on organizational climate and organizational performance.
\end{abstract}

Keywords: organizational change, organizational climate, organizational performance

\section{Introduction}

Along with improving the quality of life of the community and competition in the era of globalization, every development carried out by public organizations is required to always look excellent. Public organizations drive the mission of service to improve the welfare of the community, wherein serving the community, it is expected to appear with the best quality and competence.

In Law Number 32 of 2004 concerning the regional government, it is stated that one of the sources of regional revenue (PAD) is the result of a regional-owned company. However, PAD had no significant effect on improving the community's welfare. There are some indications that PAD has only burdened the regional government with various hidden subsidies and pseudo costs, so that PAD has no independence to carry out its business. To optimize the function of the PAD, the Kendal District Government issued a Regional Regulation Number 14 of 2003, concerning to Regional Water Supply companies that directly changed the institutional structure existing in PAD. This is intended to realize a professional, effective, and efficient bureaucratic system in carrying out activities to be able to provide quickly, easily and cheaply services to the community.

The enactment of these regulations results in organizational change, with the principle of poor structure but rich in functions. This has influenced situational aspects, where employees can be motivated to adjust to the demands of the job. Meanwhile, on the other hand, employees who are unable to adjust this paradigm change are psychologically regarded as threatening job security and causing conflict, which can have an impact on morale. These conditions require organizations to always make various efforts to improve employee and organizational performance. Based on the facts, it can be assumed that organizational climate and performance are related to organizational change which includes elements of technostructure, work procedures, and individual change (Ignatius, 2007).

\section{Literature Review}

There are many factors influence employee performance including organizational change and organizational climate. The purpose of organizational change is to control the work atmosphere, in this case, is the organizational climate, so that the members of the organization are not affected by the change takes place. A conducive organizational climate will result in increased organizational abilities or performance to be able to survive and develop, as suggested by Ignatius (2007). Therefore, it is very important to know how to create organizational climate that leads to work innovation among employees (Nybakk \& Jenssen, 2012; Shanker, Bhanugopan, van der Heijden, \& Farrell, 2017). 
Isaksen and Ekvall (2010) note that organizational climate that supports work innovation is the main point and biggest challenge in managing organizations to achieve competitive advantage. Besides, if an organization can develop organizational climate that is considered positive by individuals, this condition tends to result in a higher level of motivation, commitment and employee involvement, which leads to increase organizational performance. Importantly, organizational climate has a positive and significant effect on employee innovation and creativity in organizations (Crespell \& Hansen, 2009; Nybakk, Crespell, \& Hansen, 2011; Nybakk \& Jenssen, 2012).

\subsection{Organizational Change}

Beckhard and Pritchard (1991) argue that organizational change is a business plan that includes organizational change as a whole, and is handled by top management to improve organizational effectiveness and performance. The main purpose of organizational change is to seize opportunities, by moving from the current status quo to better conditions. Thus, sustainable performance can be the main justification for organizational change (Lozano, 2013). Organizations have become the main focus of attention and are considered to have the resources, technology and motivation to work towards more sustainable organizations.

The elements of organizational change according to Stoner, Freeman, and Gilbert $\operatorname{Jr}$ (1996) include:

1. Change in technostructure, namely a change made jointly to change aspects of the organizational structure and technology used in the production process, which includes replacing equipment, engineering processes, research techniques or production methods.

2. Change in work procedures, namely a structural change in the form of rearranging internal systems, such as communication lines, work, or management hierarchy.

3. Individual change, namely a change in employees, who try to change employee behavior by focusing on the skills, attitudes, perceptions, and expectations.

Specifically, there have been some past studies on organizational change for sustainability performance in the manufacturing sector with focus on examining the barriers to change (Neri, Cagno, Di Sebastiano, \& Trianni, 2018; Thomas-Seale, Kirkman-Brown, Attallah, Espino, \& Shepherd, 2018; Trianni, Cagno, \& Neri, 2017). However, organizational change becomes a driver of sustainable performance in the metal manufacturing industry (Feng, Huang, \& Wang, 2018; Orji, 2019).

\subsection{Organizational Climate}

Organizational climate is a set of internal features that distinguish one organization from another (Davis \& Newstrom, 1989). The elements that build the organizational climate are open organizational structures, dynamic performance standards, management style, vertical and horizontal communication, and employee involvement and participation in the organization.

Dimensions of organizational climate such as autonomy and introduction of knowledge and information seem to have a positive impact on innovative behavior (Krause, 2007). In particular, when individuals work in environments where autonomy is perceived to exist, they may experience greater free-will and take action on their own ideas and work processes thereby increasing work innovation (Si \& Wei, 2012).

Some studies have found that organizational climate has a close relationship with performance (Akbaba \& Altındağ, 2016; Cuadra-Peralta, Veloso-Besio, Iribaren, \& Pinto, 2017; Shahin, Shabani Naftchali, \& Khazaei Pool, 2014; Shanker et al., 2017). T. Akbar (2009) and Suarningsih, Alamsyah, and Thoyib (2013) found a positive effect between organizational climate on employee performance.

\subsection{Performance}

Kusnadi (2002) defines performance as any movement, action, implementation, activity or conscious action directed at achieving certain goals and targets. Factors that influence the improvement of organizational performance according to Bernardin (1993) are output quality and quantity, timeliness, work effectiveness, independence, and work commitment.

\subsection{Hypotheses Development}

The hypotheses proposed in this study are as follows:

H1: Change in technostructure has a significant effect on organizational climate

$\mathrm{H} 2$ : Change in work procedures has a significant effect on organizational climate

H3: Change in individuals has a significant effect on organizational climate 
H4: Change in technostructure, work procedures, and individual simultaneously has a significant effect on organizational climate.

H5: Change in organizational climate has a significant effect on organizational performance

\section{Research Methods}

The sample of this study was 149 employees of PDAM Tirta Daya Maju, Kendal Regency in Indonesia. The data analysis technique used is multiple and simple linear regression with SPSS version 11. Hypothesis testing is done by t-test to determine the effect partially and $\mathrm{F}$ test to find out the effect simultaneously.

The data in this study were obtained using 149 questionnaires distributed to respondents, but there were 114 questionnaires were returned and suitable to use. The number of male respondents was $79.8 \%$, and $20.2 \%$ were women. Respondents with elementary school education were $9.6 \%$, junior high school was $10.5 \%$, senior high school was $70.2 \%$, middle experts were $4.4 \%$, and undergraduate program was $5.3 \%$. This shows that at the time of the study, the education level of respondents was dominated by those with high school education. $2.6 \%$ of respondents were less than 30 years old, $42.1 \%$ were between the ages of 30-40 years, and $55.3 \%$ were over 40 years old.

\section{Results}

Table 1. Multiple regression analysis

\begin{tabular}{llll}
\hline & $\boldsymbol{\beta}$ & t-ratio & $\boldsymbol{\rho}$ \\
\hline Change in technostructure & -0.105 & -2.371 & 0.019 \\
\hline Change in work procedures & 0.174 & 2.050 & 0.043 \\
\hline Change in individuals & 0.125 & 2.155 & 0.033 \\
\hline Constant & 3.327 & 1.471 & 0.144 \\
\hline Adjusted $\mathbf{R}^{\mathbf{2}}$ & 0.100 & \\
\hline F-Ratio & 5.182 & \\
\hline $\mathbf{\rho}$ & 0.0020 & \\
\hline $\mathbf{D W}$ & 1.449 & & \\
\hline $\mathbf{N}$ & 114 & & \\
\hline
\end{tabular}

a. Dependent variable: Organizational Climate

Table 1 performs the final regression equation model as follows:

$$
\mathrm{y}=3.327-0.105 \times 1+0.174 \times 2+0.125 \times 3
$$

The results of this study indicate that change in technostructure has a negative sign which means that between technological change in structure and organizational climate is inversely proportional. The high change in technostructure in the organization has resulted in a declining organizational climate. Furthermore, change in work procedures and individual have a positive sign, which indicates that increasingly good change in work procedures and the individual can improve the organizational climate.

Table 2. Simple regression analysis

\begin{tabular}{llll}
\hline & $\boldsymbol{\beta}$ & t-ratio & $\boldsymbol{\rho}$ \\
\hline Organizational climate & 0.212 & 2.321 & 0.022 \\
\hline Constant & 13.860 & 18.658 & 0.000 \\
\hline $\mathbf{R}^{\mathbf{2}}$ & 0.046 & & \\
\hline F-Ratio & 5.388 & & \\
\hline $\boldsymbol{\rho}$ & 0.022 & & \\
\hline
\end{tabular}


$\mathbf{N}$

a. Dependent variable: Organizational performance

Based on Table 2, it shows the simple regression equation model as follows:

$$
\mathrm{Z}=\mathbf{1 3 . 8 6 0}+\mathbf{0 . 2 1 2 y}
$$

The regression coefficient in the organizational climate has a positive sign. This indicates that organizational climate change is getting better and can improve organizational performance. Hypothesis 1 testing produces a value of $t$ count of $-2,371$ with a significance level of 0.019 . This shows that hypothesis 1 is accepted. Testing of hypothesis 2 produces a value of $t$ count of 2.050 with a significance level of 0.043 . This shows that hypothesis 2 is accepted. Testing of hypothesis 3 produces a value of $t$ count of 2.155 with a significance level of 0.033 . This shows that hypothesis 3 is accepted. Testing of hypothesis 4 uses a simultaneous test that the calculated $F$ value is 5.182 with a significance value of 0.002 which means that hypothesis 4 is accepted. Testing hypothesis 5 produces a value of $t$ count of 2.321 with a significance level of 0.022 . This shows that hypothesis 5 in this study was accepted.

\subsection{Coefficient of Determination $\left(R^{2}\right)$}

The magnitude of the coefficient of determination of the simple regression model in this study is 0.046 or $4.6 \%$. This can be interpreted that as much as $4.6 \%$ organizational performance can be explained by the organizational climate.

\section{Discussion}

Organizational change that includes the change in technostructure, work procedures, and individual, in this study show a significant effect on organizational climate. Change in technostructure has a negative effect on organizational climate. This means that the higher technostructure change in the organization can result in a decrease in the organizational climate. The reason is the application of computerized technology applied to data processing in PDAM Tirta Daya Maju without being balanced with adequate knowledge from employees. Therefore, it takes employees who are skilled in processing data using a computerized system. With the application of computerized technology, it is expected that employees can carry out a more efficient work process so that it can support the productivity of the company. With this change, company leaders are required to be able to prepare their employees to be skilled in applying the use of computers in carrying out the task of providing services to the community. So in this situation employees who feel they do not have the skills to use a computer system will feel unable to work, and will be excluded from fellow workers who have mastered the use of computers. This will obviously lead to discomfort in work and can result in a decrease in the quality of the organizational climate expected by the company.

Structural change in the form of specialization of work, departmentalization, centralization, and decentralization of work result in the creation of division of labor, appropriate lines of authority, change in management control range, description of positions, fields of responsibility, and reporting relationships, which in the implementation of downsizing structures but main tasks and maximum function. Or in other words, organizations that are poor in structure but rich in functions. This has the effect of threatening security and conflict which affects decreasing work morale, high absenteeism and low work motivation that will create an organizational climate that is not conducive (Leavitt, 1996). The results of this study support the research conducted by Khasawneh (2018); Niemi (2018); Pangumpia (2013) which concluded that organizations that are associated with factors applying technology change such as the use of communication technology can have a significant impact on the organizational climate.

Change in work procedures has a positive and significant effect on organizational climate. This was conceived by the intention that organizational climate change was largely determined by the size of the level of change in work procedures. Simplification of work procedures, work efficiency, implementation of the chain of command, with the new system increasingly clarifying employees in work, must report to whom, who is the boss, how many subordinates can be directed effectively and efficiently by a leader, so that this directly affects the creation of an improved organizational climate. Research conducted by Supriyadi (2005) found that employee commitment, job satisfaction, and change in organizational structure are factors that influence organizational change.

Individual change has a positive and significant effect on organizational climate. This means that individual change is increasing such as improving employee skills, motivation, attitudes, perceptions, employee expectations, and the creation of a good work environment, the better the organizational climate manifests in the company. This result is in line with the study conducted by Marinova, Cao, and Park (2019); Sukengsari and Sobirin (2005); Zientara and Zamojska (2018) suggesting that among one of the organizational change variables in the form of change in individual employees has a positive and significant effect on the change in employee behavior and organizational climate. 
Change in technostructure, work procedures, and individual jointly influence the organizational climate of the company. This means that change in both the bad or high and low organizational climate is largely determined by change in technology structure, change in work procedures, and individual change that occur in the company.

Organizational climate has a positive and significant effect on organizational performance. This means that change in the level of organizational performance is largely determined by the high and low organizational climate that occurs in the company. The more employees get treatment, positive support, and good attention from the leadership, the employees will get protection and protection, so that all employees will strive to create a conducive work climate, so employees will try to optimize their performance (Mor Barak, Cherin, \& Berkman, 1998). The better organizational climate, employee performance will be better driven, which means increased organizational performance. In line with the research conducted by (A. B. Akbar, Udin, Wahyudi, \& Djastuti, 2018; Audenaert, Decramer, Lange, \& Vanderstraeten, 2016; Bosak, Dawson, Flood, \& Peccei, 2017; Nugroho, 2013; Sudarmanto Alugoro, 2002) show that organizational climate and motivation have a positive effect on employee performance.

\section{Conclusion}

This study concludes that 1) change in technostructure affect the organizational climate; 2) change in work procedures affect the organizational climate; 3) individual change affect the organizational climate; 4) change in technology structure, work procedures and individual simultaneously affect organizational climate; and 5) organizational climate affects organizational performance.

The implications of this study are related to efforts to create a better organizational climate and improve organizational performance, the application of technological change must be carried out together with increasing employee knowledge and skills about new technology. This can be done by holding or involving employees in continuous training, courses or training programs. Organizations also need to place employees according to their work and expertise. For this reason, management can do rolling or transfer to employees.

Management must be able to motivate employees towards positive performance to realize the organization's vision and mission, such as a change in employee attitudes, perceptions and expectations of the organization. Management places employees according to professionalism and not based on seniority. Management provides opportunities for employees to attend school or lectures after work time is over, also management can provide compensation following with the tenure of the employees.

The limitations of this study are the objects of research that are still limited when compared to the conditions in similar companies. Therefore, future research needs to expand the research area so that the research model developed can be a reference for PDAMs in other regions.

\section{References}

Akbaba, Ö., \& Altındağ, E. (2016). The Effects of Reengineering, Organizational Climate and Psychological Capital on the Firm Performance. Procedia - Social and Behavioral Sciences, 235, 320-331. https://doi.org/10.1016/j.sbspro.2016.11.038

Akbar, A. B., Udin, W. S., \& Djastuti, I. (2018). Spiritual Leadership and Employee Performance: Mediating Role of Organizational Commitment in Indonesian Public University. Journal of Engineering and Applied Sciences, 13(12), 4344-4352.

Akbar, T. (2009). Pengaruh Iklim Organisasi Terhadap Kinerja Karyawan Pada PT. PLN (Persero) Wilayah Sumatera Utara Cabang Medan. Universitas Sumatera Utara.

Audenaert, M., Decramer, A., Lange, T., \& Vanderstraeten, A. (2016). Setting high expectations is not enough: Linkages between expectation climate strength, trust, and employee performance. International Journal of Manpower, 37(6), 1024-1041. https://doi.org/10.1108/IJM-12-2015-0201

Beckhard, R. A., \& Pritchard, W. (1991). changing the essence: The art of creating and leading fundamental change in organizarion. Jossey Bass Publishers.

Bernardin, J. (1993). The Function of The Executive. Cambridge, Ma. Research of Harvard University.

Bosak, J., Dawson, J., Flood, P., \& Peccei, R. (2017). Employee involvement climate and climate strength: A study of employee attitudes and organizational effectiveness in UK hospitals. Journal of Organizational Effectiveness: People and Performance, 4(1), 18-38. https://doi.org/10.1108/JOEPP-10-2016-0060

Crespell, P., \& Hansen, E. (2009). Antecedents to innovativeness in the forest products industry. Journal of Forest Products Business Research, 6(1), 1-20. 
Cuadra-Peralta, A. A., Veloso-Besio, C., Iribaren, J., \& Pinto, R. (2017). Intervention for supervisors, based on social skills and leadership, in order to improve organizational climate perception and organizational performance outcomes. Journal of Organizational Change Management, 30(2), 281-292. https://doi.org/10.1108/JOCM-10-2016-0205

Davis, K., \& Newstrom, J. W. (1989). Human behavior at work: Organizational behavior. McGraw-Hill.

Feng, C., Huang, J.-B., \& Wang, M. (2018). Analysis of green total-factor productivity in China's regional metal $\begin{array}{lllll}\text { industry: A meta-frontier approach. Resources } & \text { Policy, }\end{array}$ https://doi.org/10.1016/j.resourpol.2018.05.008

Ignatius, W. (2007). Dasar-Dasar Ilmu Organisasi. Andi: Yogyakarta.

Isaksen, S. G., \& Ekvall, G. (2010). Managing for innovation: The two faces of tension in creative climates. Creativity and Innovation Management, 19(2), 73-88. https://doi.org/10.1111/j.1467-8691.2010.00558.x

Khasawneh, O. Y. (2018). Technophobia without boarders: The influence of technophobia and emotional intelligence on technology acceptance and the moderating influence of organizational climate. Computers in Human Behavior, 88, 210-218. https://doi.org/10.1016/j.chb.2018.07.007

Krause, T. (2007). The effective safety leader: Personality, values and emotional commitment. Occupational Hazards, 69(9), 24.

Kusnadi, H. (2002). Masalah, Kerjasama, Konflik, dan Kinerja. Torada, Malang.

Leavitt, W. M. (1996). High Pay and Low Morale - Can High Pay, Excellent Benefits, Job Security, and Low Job Satisfaction Coexist in a Public Agency?. Personnel Administration, 25(3), 333-341. https://doi.org/10.1177/009102609602500306

Lozano, R. (2013). Are companies planning their organisational changes for corporate sustainability? An analysis of three case studies on resistance to change and their strategies to overcome it. Corporate Social Responsibility and Environmental Management, 20(5), 275-295. https://doi.org/10.1002/csr.1290

Marinova, S. V., Cao, X., \& Park, H. (2019). Constructive organizational values climate and organizational citizenship behaviors: A configurational view. Journal of Management, 45(5), 2045-2071. https://doi.org/10.1177/0149206318755301

Mor Barak, M. E., Cherin, D. A., \& Berkman, S. (1998). Organizational and personal dimensions in diversity climate: Ethnic and gender differences in employee perceptions. The Journal of Applied Behavioral Science, 34(1), 82-104. https://doi.org/10.1177/0021886398341006

Neri, A., Cagno, E., Di Sebastiano, G., \& Trianni, A. (2018). Industrial sustainability: Modelling drivers and mechanisms with barriers. Journal of Cleaner Production, 194, 452-472. https://doi.org/10.1016/j.jclepro.2018.05.140

Niemi, T. (2018). Digital Technology as a Source of Creative Organizational Resource and Service Delivery: Building a Climate for Organizational Creativity with Deliberative Democracy. Journal of Media Critiques, 4(14), 241-253.

Nugroho, A. B. (2013). Pengaruh Motivasi Dan Disiplin Kerja Terhadap Kinerja Karyawan Konveksi IV PT. Dan Liris Di Sukoharjo. Universitas Muhammadiyah Surakarta.

Nybakk, E., \& Jenssen, J. I. (2012). Innovation strategy, working climate, and financial performance in traditional manufacturing firms: An empirical analysis. International Journal of Innovation Management, 16(2), 1250008. https://doi.org/10.1142/S1363919611003374

Nybakk, E., Crespell, P., \& Hansen, E. (2011). Climate for innovation and innovation strategy as drivers for success in the wood industry: moderation effects of firm size, industry sector, and country of operation. Silva Fennica, 45(3), 415-430. https://doi.org/10.14214/sf.110

Orji, I. J. (2019). Examining barriers to organizational change for sustainability and drivers of sustainable performance in the metal manufacturing industry. Resources, Conservation and Recycling, 140, 102-114. https://doi.org/10.1016/j.resconrec.2018.08.005

Pangumpia, F. (2013). Pengaruh iklim komunikasi organisasi terhadap produktivitas kerja karyawan di bank prisma dana Manado. Jurnal Acta Diurna, 2(2). 
Shahin, A., Shabani Naftchali, J., \& Khazaei Pool, J. (2014). Developing a model for the influence of perceived organizational climate on organizational citizenship behaviour and organizational performance based on balanced score card. International Journal of Productivity and Performance Management, 63(3), 290-307. https://doi.org/10.1108/IJPPM-03-2013-0044

Shanker, R., Bhanugopan, R., van der Heijden, B. I. J. M., \& Farrell, M. (2017). Organizational climate for innovation and organizational performance: The mediating effect of innovative work behavior. Journal of Vocational Behavior, 100, 67-77. https://doi.org/10.1016/j.jvb.2017.02.004

Si, S., \& Wei, F. (2012). Transformational and transactional leaderships, empowerment climate, and innovation performance: A multilevel analysis in the Chinese context. European Journal of Work and Organizational Psychology, 21(2), 299-320. https://doi.org/10.1080/1359432X.2011.570445

Stoner, J. A., Freeman, R. E., \& Gilbert, D. R. Jr. (1996). Manajemen jilid I. Jakarta: PT Bhuana Ilmu Populer, Terjemahan.

Suarningsih, N. L. P., Alamsyah, A., \& Thoyib, A. (2013). Pengaruh Iklim Organisasi terhadap Komitmen Organisasional dan Kinerja Karyawan di Rumah Sakit. Jurnal Aplikasi Manajemen, 11(2), 233-240.

Sudarmanto Alugoro, K. (2002). Analisis Pengaruh Iklim Kerja Terhadap Kepuasan Kerja Pegawai di Sekretariat Daerah Kota Semarang. Program Pascasarjana Universitas Diponegoro.

Sukengsari, E. M., \& Sobirin, A. (2005). Implikasi Restrukturisasi Kelembagaan Terhadap Perubahan Perilaku Karyawan Dan Iklim Oganisasi (Studi Kasus Pada Badan Kesatuan Dan Perlindungan Masyarakat Propinsi DIY). Jurnal Fakultas Hukum UII.

Supriyadi, A. (2005). Analisis Pengaruh Kepuasan Kompensasi, Pemberdayaan Dan Budaya Organisasi Terhadap Kinerja Karyawan (Studi Empiris Pada Pt Bina Guna Kimia). Program Pasca Sarjana Universitas Diponegoro.

Thomas-Seale, L., Kirkman-Brown, J., Attallah, M., Espino, D., \& Shepherd, D. (2018). The barriers to the progression of additive manufacture: perspectives from UK industry. International Journal of Production Economics, 198, 104-118. https://doi.org/10.1016/j.ijpe.2018.02.003

Trianni, A., Cagno, E., \& Neri, A. (2017). Modelling barriers to the adoption of industrial sustainability measures. Journal of Cleaner Production, 168, 1482-1504. https://doi.org/10.1016/j.jclepro.2017.07.244

Zientara, P., \& Zamojska, A. (2018). Green organizational climates and employee pro-environmental behaviour in the hotel industry. Journal of Sustainable Tourism, 26(7), 1142-1159. https://doi.org/10.1080/09669582.2016.1206554 